\title{
Field evaluation of Hevea brasiliensis clones for the incidence of white root disease in Nigeria
}

\author{
Emmanuel O. Akpaja ${ }^{1}$ and Nicholas O. Ogbebor ${ }^{2 *}$ \\ ${ }^{1}$ Department of Plant Biology and Biotechnology, University of Benin, PMB 1154, Benin City, Nigeria \\ ${ }^{2}$ Agronomy Department, Rubber Research Institute of Nigeria, PMB 1049, Benin City, Nigeria
}

(Manuscript Received: 07-12-2020, Revised:17-02-2021, Accepted:25-02-2021)

\begin{abstract}
Incidence and severity of white root disease affecting rubber trees were determined in five rubber clones of 10 and 35 years old. The percentage of infection, aggregate failure, level of infectivity and gross economic loss were evaluated. There were variations in resistance to white root disease among rubber clones studied. However, no rubber clone was free from this disease even though there were significant $(\mathrm{P}>0.05)$ differences in the ability of the pathogen to attack different clones. Results of disease index in the multiclonal plot were compared with those from plots of specific clones of rubber. Percentage infection in 35-year-old rubber plots was significantly $(\mathrm{P}>0.05)$ higher than 10 -year-old rubber trees. The level of infectivity of white root disease pathogen was generally high with the lowest value for missing stands of $3.33 \pm 1.67$ (representing 41.63 per cent of expected neighbouring stands) and as many as $6.00 \pm 0.56$ (representing 75 per cent of expected neighbouring stands) in 10 and 35-year-old rubber plots, respectively. The estimated gross economic losses (N 113,652.30 to 274,734.30) per year recorded in the study were high. This study indicates the need for regular monitoring of white root disease in rubber plantations so that the disease can be managed and controlled at an early stage of the disease occurrence.
\end{abstract}

Keywords: Hevea clones, disease incidence, pathogen, white root disease

\section{Introduction}

White root disease, caused by the fungus Rigidoporus lignosus (Klotzsch) lmazeki, is regarded as the most destructive disease of the Para rubber tree (Hevea brasiliensis Muell. Arg.) in Nigeria. According to Otoide (1978), white root disease accounts for about 94 per cent of incidences of all root diseases and kills up to five Hevea trees $\mathrm{ha}^{-1}$ year $^{-1}$. Over a period of time, half of the rubber trees in a plantation are lost due to the disease. In West Africa, white root disease is responsible for yield losses of up to 50 per cent in old rubber plantations (Nandris et al., 1983; Ogbebor et al., 2014; Ogbebor et al., 2015).

The disease is present in all rubber growing regions of the world (Nandris et al., 1983) except in India (Jayasinghe, 2010; Ogbebor et al., 2015). The disease is severe in Cote d' Ivoire, Nigeria and
Sri Lanka (Rajalakshmy and Jayarathnam, 2000), and a significant, endemic problem in Gabon, Indonesia, Malaysia and Thailand (IRRDB, 2000). The incidence and pathogenicity of the pathogen have also been reported on Triplochiton scleroxylon in Nigeria (Begho and Ekpu, 1987). According to Bodah (2017) root rot symptoms are a major threat because the damage starts below the ground, where the first symptoms are not visible. When the symptoms become visible on the above-ground part of the plant, the yield is already affected, and the survival of the affected plants are very remote.

In consonance with the assertion by Otoide (1978) and Aigbekaen et al. (2004), the disease is one of the major maladies affecting small-holding rubber farmers' plots in Nigeria. The small-holding rubber farmers' income is thus adversely affected due to the crop yield loss. Consequently,

*Corresponding Author: ogbeb06@yahoo.com 
determining the current status of the disease is of utmost importance because this information could provide insight in controlling or managing the disease at the early stages of its infection. The objective of this study was to determine the incidence and severity of white root disease in rubber plantations at the Rubber Research Institute of Nigeria, Iyanomo, Benin City, Nigeria. The infectivity of the pathogen was also considered, along with the economic implication of losing rubber stands in plantations.

\section{Materials and methods}

\section{Study area and general background}

The study area was at the Main Station of the Rubber Research Institute of Nigeria, Iyanomo $\left(06^{0} 09^{\prime} 26.9^{\prime \prime} \mathrm{N}, 05^{0} 35^{\prime} 56.8^{\prime \prime} \mathrm{E}\right)$, about 19 kilometres from Benin City, Edo State, Nigeria. The incidence and severity of white root disease in rubber trees were determined in five rubber clones, namely; PR107, RRIC45, NIG. 800, GT1, and in Multi Clonal Plots (MCP). Rubber plots of two age group, 10 and 35 years, for each of these clones were evaluated for disease incidence and severity.

\section{Selection of plots}

Three replicate plots, each having 50 planting points, were evaluated for incidence and severity of white root disease on a clonal basis. Planting points were positions originally planted with rubber. The selection of these plots, per clone and age, were randomly selected among established monoclonal rubber plantations except for MCP deliberately included in the study.

\section{Evaluation of rubber trees for incidence and severity of white root disease}

The recommended method of checking the lateral roots of rubber for rhizomorph of the pathogen (IRRDB, 2000; Ogbebor et al., 2019) was employed. The following information was recorded for each planting point originally planted with rubber in the chosen plots. It was determined whether or not the planting points were now occupied by (i) uninfected stumps, (ii) infected stumps, (iii) missing stands, (iv) healthy trees or (v) diseased trees. A missing stand refers to a planting point that no longer has any rubber tree or stump, dead or alive. Other parameters determined were as follows:

(i) Aggregate failure: This was the sum total of missing stands and supplied stands.

(ii) Percentage infection: This was calculated as follows:

$$
\frac{\text { Number of infected trees }}{\text { Total number of tress }} \times \frac{100}{1}
$$

(iii) Disease index (DI): This was used to determine the level of severity of disease as described by Parry (1990).

$$
D I=\frac{(0 x a)+(1 x b)+(2 x c)+(3 x d)+(4 x e)}{a+b+c+d+e} \times \frac{100}{4}
$$

Where, $0,1,2,3$ and 4 denote infection categories, and a,b,c,d, and e are the number of plants falling into each category.

The rating adopted for determining the incidence and severity of white root disease on rubber trees are shown in Table 1.

Table 1. White root disease rating and description

\begin{tabular}{lcl}
\hline $\begin{array}{l}\text { Category/rating } \\
\text { of infection }\end{array}$ & Score & \multicolumn{1}{c}{ Description } \\
\hline No infection & 0 & $\begin{array}{l}\text { No rhizomorph on stem } \\
\text { base or lateral roots }\end{array}$ \\
Light infection & 1 & $\begin{array}{l}\text { Rhizomorph present, tissue } \\
\text { not penetrated }\end{array}$ \\
Moderate infection & 2 & $\begin{array}{l}\text { Portion of one lateral root } \\
\text { penetrated }\end{array}$ \\
Severe infection & 3 & $\begin{array}{l}\text { More than one lateral root } \\
\text { rotted }\end{array}$ \\
Very severe infection & 4 & $\begin{array}{l}\text { All roots rotted and tree } \\
\text { dying or dead }\end{array}$ \\
\hline
\end{tabular}

(iv) Level of infectivity: This was carried out to determine the pathogen's level of virulence from an infection locus (Ogbebor et al., 2013). Diseased and dead rubber stumps (infection loci) heavily studded with the fruiting bodies of Rigidoporus lignosus equal to or greater than 11 were chosen. This was done by selecting eight immediate neighbouring stands to the diseased and dead rubber stump, as shown in Figure 1. 
The method of checking the lateral roots of rubber trees for the presence of rhizomorph growth was employed. This was determined by applying the ratings adopted for determining the incidence and severity of white root disease on rubber trees, as shown in Table 1.

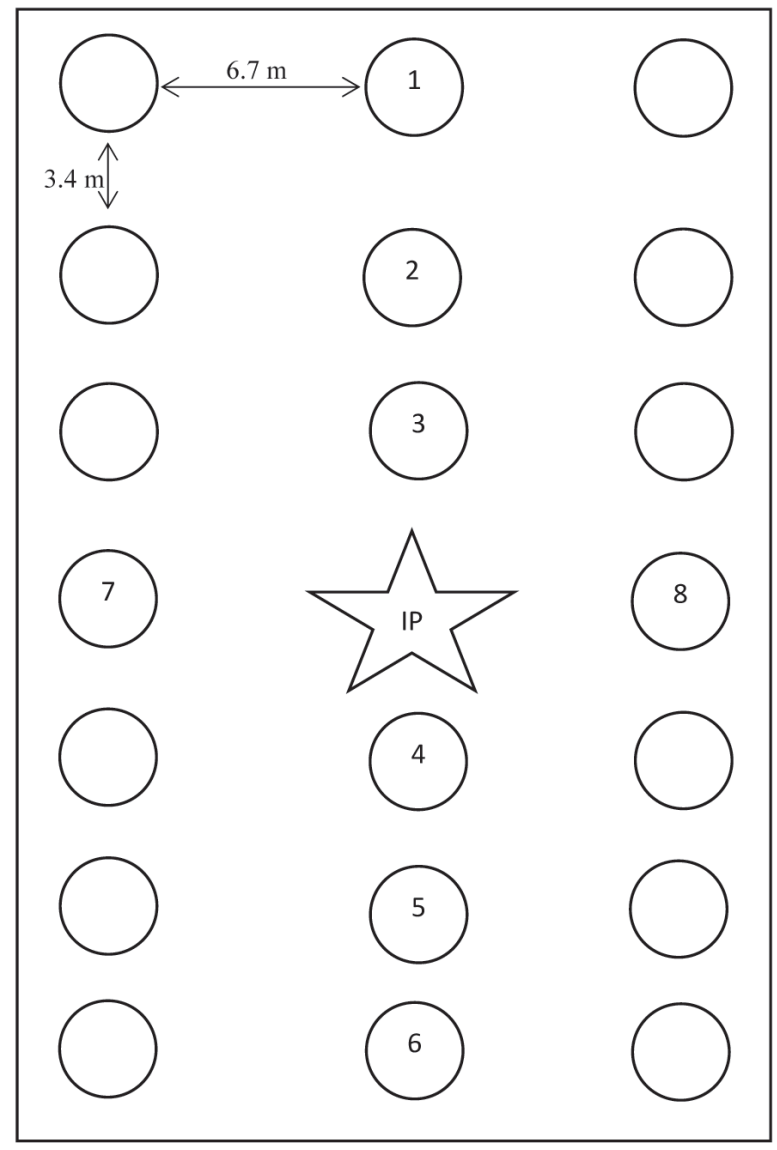

Fig. 1. Position of a selected infection locus in relation to immediate neighbouring rubber trees IP = Infection point

(v) Gross Economic Loss (GEL): To determine the impact of the aggregate failure on the income from the plantations, estimation was made of the gross economic loss occasioned by the absence of the rubber trees in some planting points. The gross economic loss was calculated per year using the formula given below (Ogbebor et al., 2013). In this study, the price of the cup lump was substituted for the price for $1 \mathrm{~kg}$ of dry rubber content.

$$
\mathrm{GEL}=355-\frac{(\mathrm{Wp}+\mathrm{Rd} \times \mathrm{Cp} \times \mathrm{Af})}{2}
$$

where, $\mathrm{Wp}=$ Wintering period (approximately 21 days) during which rubber trees were not tapped, $\mathrm{Rd}=$ Approximate number of rain days (21 days) where it was impossible to tap or when tapped, latex in the cup was washed away by heavy rainfall, $\mathrm{Cp}=$ Current price of cup lump (current average price for a cup is $\mathrm{N}$ 57:00), $\mathrm{Af}=$ Aggregate failure, which is the number of missing stands + Number of dead trees + number of stumps per hectare

\section{Data analysis}

The data generated during the course of this study were subjected to descriptive and inferential statistics such as mean, percentage, standard error and analysis of variance (ANOVA). The means were separated using the least significant difference (LSD).

\section{Results and discussion}

This study has shown that the importance of the white root disease of the rubber tree caused by Rigidoporus lignosus cannot be overemphasized. Jayaratne et al. (1997) mentioned that rubber root diseases have always attracted less attention than other maladies, probably because of their unseen and insidious nature. Studies carried out by Geiger et al. (1986) and Nicole and Nicole (1991) reported that the pathogen produces both lignin and cellulosedegrading enzymes. Galliano et al. (2006) showed that the pathogen produces two ligninolytic enzymes, namely lacasse and Mn-peroxidase, to achieve effective lignin degradation.

According to Jayasinghe (2010), controlling white root disease is a challenging task as the causative agent affect the root system of many woody plants, and no tolerant rubber seedlings have been reported from any part of the world to date. Therefore, it was concluded that the development of resistant rootstock would be an ideal solution for the management of white root disease. The result of this study showed variations in clonal resistance to white root disease. As shown in Table 2, there was no rubber clone that was free from this disease even though there were significant $(\mathrm{P}>0.05)$ differences in the ability of the pathogen to attack 
the clones. Clonal variability observed in this study had been supported by earlier work of Suneerat et al. (2012), where it was reported that clonal variability existed amongst the rubber clones evaluated on white root disease.

Moreover, the results of the multiclonal plots (MCP) further support this opinion. This is because the percentage infection and disease index values compared favourably with those from plots of specific clones of rubber. For 10-year-old rubber plots, the percentage of infection ranged from 1.70 per cent in RRIC 45 to 7.90 per cent in MCP and 21.10 per cent in GT 1 .

Table 2. Incidence and severity of white root disease and inoculum size in selected rubber clones

\begin{tabular}{lccccc}
\hline $\begin{array}{l}\text { Rubber } \\
\text { clone }\end{array}$ & \multicolumn{2}{c}{$\begin{array}{c}\text { Percentage } \\
\text { infection }(\%)\end{array}$} & & \multicolumn{2}{c}{$\begin{array}{c}\text { Disease } \\
\text { index }\end{array}$} \\
\cline { 2 - 3 } \cline { 5 - 6 } \cline { 5 - 6 } & 10 years & $\mathbf{2 3 5}$ years & & 10 years & $\mathbf{2 3 5}$ years \\
\hline PR 107 & 2.40 & 8.20 & & 1.10 & 3.30 \\
RRIC 45 & 1.70 & 28.70 & & 0.40 & 17.20 \\
NIG 800 & 3.40 & 34.30 & & 1.00 & 16.90 \\
GT1 & 21.10 & 39.50 & & 13.40 & 29.31 \\
RRIM 707 & 1.70 & 6.50 & & 0.40 & 3.06 \\
MCP & 7.90 & 28.50 & & 3.1 & 16.20 \\
LSD $_{(0.05)}$ & 5.37 & 9.58 & & 3.7 & 6.83 \\
\hline
\end{tabular}

In much older ( $\geq 35$ years) rubber plots, the percentage of infection was significantly $(\mathrm{P}>0.05)$ higher than what was reported for young rubber trees of age 10 years. The least percentage of infection was 6.50 per cent (RRIM 707), and the highest value was found in GT1 (39.50 per cent). As expressed by disease indices (Table 2), the severity of the disease indicated that the pathogen was well established in most of the plots visited. A disease index of 13.40 and 29.30 in GT1 for 10 years and $\geq 35$-year-old rubber tree showed that the pathogen was "deeply rooted" in the plantations. The disease situation becomes more serious that only 50 points planted with rubber trees were used in this study. A complete survey of all the points planted with rubber trees would give a clear picture of the extent of damage caused by $R$. lignosus in causing white root disease in rubber. It appeared that the lands were not properly prepared, resulting in the occurrence of substantial plant parts remaining in the soil. This probably acted as a food base for the pathogen and hence the high incidence of missing stands and aggregate failures in the plots examined. Also, it appeared that the white root disease is not being monitored and controlled periodically. This can be deduced from the fact that, per 50 planting points sampled for each plot and clone for any particular age, the overall missing stands were as high as 32.00 \pm 2.00 , which is more than 50 per cent of the planting points examined (Table 3 ). The level of infectivity of the white root disease pathogen was generally high. This is evident from the fact that out of the eight neighbouring planting points assessed, relative to an infection locus, the lowest value for missing stands was $3.33 \pm 1.67$ (representing 41.63 per cent of expected neighbouring stands) and as many as $6.00 \pm 0.56$ (representing 75 per cent of expected neighbouring stands) in 10 and 35 -year-old rubber plots, respectively. The only exception was RRIC 45 that did not have any missing stand at the age of 10 years. The disease index of $26.21 \pm 2.21$ cannot, however, be overlooked (Table 4). There is, therefore, the need to give prompt and regular attention to this disease in Nigerian rubber plantations. This assertion is in line with earlier findings reported by Ogbebor et al. (2013). It was demonstrated that white root disease incidence is reduced in plantations, where good cultural practices are observed. According to Martinez-Ferri (2016), detection of infection on roots before aerial symptoms are observed would help facilitate the application of control measures during the early stage of the infection, thereby avoiding tree death and further spreading the root disease. The high level of infectivity recorded in this study may not only suggest the virulence of the pathogen. It may also have been aggravated because the regular attention given to preventing/ controlling the disease has dwindled or no more in practice in many plantations over the years.

Ogbebor et al. (2013) looked at the incidences of white root disease as it affects the yield of rubber produce from the plantation as an entity. But this study emphasizes the effect of white root disease based on individual rubber tree as an entity with concern for the local farmers who form the bulk of rubber production in Nigeria and who lack the fund to carry out good cultural practices in their plantations. 
Table 3. Level of failures of rubber trees establishment in selected plots

\begin{tabular}{|c|c|c|c|c|c|c|c|c|}
\hline \multirow{2}{*}{$\begin{array}{l}\text { Rubber } \\
\text { clone }\end{array}$} & \multicolumn{4}{|c|}{10 years old rubber trees } & \multicolumn{4}{|c|}{$\geq 35$ years old rubber trees } \\
\hline & $\begin{array}{l}\text { Missing } \\
\text { stands }\end{array}$ & $\begin{array}{l}\text { Supplies } \\
\text { stands }\end{array}$ & $\begin{array}{l}\text { Aggregate } \\
\text { failure }\end{array}$ & $\begin{array}{l}\text { Gross } \\
\text { E. loss }\end{array}$ & $\begin{array}{l}\text { Missing } \\
\text { stands }\end{array}$ & $\begin{array}{c}\text { Supplies } \\
\text { stands }\end{array}$ & $\begin{array}{c}\text { Aggregate } \\
\text { failure }\end{array}$ & $\begin{array}{l}\text { Gross } \\
\text { E. loss }\end{array}$ \\
\hline PR 107 & $22.00 \pm 3.79^{y}$ & $2,00 \pm 0.58$ & $23,0 \pm 3.21$ & $205,827.00$ & $29.33 \pm 3.76$ & $0.00 \pm 0.00$ & $30.7 \pm 3.17$ & $274,734.30$ \\
\hline RRIC 45 & $12.70 \pm 2.03$ & $4.67 \pm 1.20$ & $12.70 \pm 2.03$ & $113,652.30$ & $15.70 \pm 3.93$ & $0.33 \pm 0.33$ & $17.0 \pm 3.21$ & $125,133.00$ \\
\hline NIG 800 & $11.70 \pm 2.72$ & $2.00 \pm 0.57$ & $12.70 \pm 2.19$ & $113,652.30$ & $13.30 \pm 0.33$ & $3.00 \pm 0.52$ & $14.00 \pm 0.00$ & $125,286.00$ \\
\hline GT1 & $32.00 \pm 2.00$ & $0.67 \pm 0.33$ & $33.30 \pm 2.19$ & $209,001.70$ & $29.30 \pm 1.33$ & $0.33 \pm 0.33$ & $30.70 \pm 1.20$ & $274,734.30$ \\
\hline RRIM 707 & $12.67 \pm 13.30$ & $4.67 \pm 1.20$ & $13.00 \pm 2.08$ & $116,337.00$ & $27.00 \pm 4.58$ & $0.33 \pm 0.33$ & $27.30 \pm 4.81$ & $242,307.70$ \\
\hline $\mathrm{MCP}$ & $20.30 \pm 0.88$ & $3.30 \pm 2.33$ & $21.00 \pm 1.00$ & $187,929.00$ & $28.79 \pm 1.45$ & $0.00 \pm 0.00$ & $29.30 \pm 1.45$ & $262,205.70$ \\
\hline $\mathrm{OM}$ & $18.31 \pm 3.22$ & $2.89 \pm 0.66$ & $19.28 \pm 2.24$ & $172,536.72$ & $23.89 \pm 3.01$ & $0.66 \pm 0.47$ & $24.8 \pm 2.31$ & $221,935.20$ \\
\hline $\operatorname{LSD}_{(0.05)}$ & 1.71 & 0.27 & 5.49 & - & 4.98 & 0.77 & 4.98 & - \\
\hline
\end{tabular}

$\mathrm{MCP}=$ Multi clonal plot; $\mathrm{Y}=$ Mean of three replicates \pm standard error; $\mathrm{OM}=$ Overall mean

Table 4. Infectivity of selected stumps of six rubber clones in selected infective centres

\begin{tabular}{lcccc}
\hline Rubber clones & $\begin{array}{c}\text { 10 years old rubber plot } \\
\text { DI }\end{array}$ & $\begin{array}{c}\text { Neighbouring } \\
\text { missing stands }\end{array}$ & $\begin{array}{c}\text { 35 years old rubber plot } \\
\text { DI }\end{array}$ & $\begin{array}{c}\text { Neighbouring } \\
\text { missing stands }\end{array}$ \\
\hline PR107 & $12.50 \pm 6.51^{x}$ & $5.33 \pm 0.33$ & $23.96 \pm 8.13$ & $4.00 \pm 0.53$ \\
RRIC 45 & $26.21 \pm 12.21$ & $0.00 \pm 0.00$ & $13.54 \pm 6.33$ & $6.00 \pm 0.56$ \\
NIG 800 & $8.54 \pm 2.80$ & $4.00 \pm 2.08$ & $21.87 \pm 6.51$ & $4.33 \pm 133$ \\
GT1 & $11.46 \pm 4.17$ & $3.33 \pm 1.67$ & $19.30 \pm 9.08$ & $4.00 \pm 1.16$ \\
RRIM 707 & $22.92 \pm 8.90$ & $5.00 \pm 1.00$ & $20.84 \pm 4.54$ & $3.67 \pm 1.76$ \\
MCPy & $13.54 \pm 10.57$ & $4.00 \pm 1.53$ & $8.34 \pm 2.75$ & $3.67 \pm 0.33$ \\
Overall mean $^{\text {M }}$ & $15.8 \pm 7.53$ & $3.61 \pm 1.10$ & $18.05 \pm 6.22$ & $4.29 \pm 0.95$ \\
LSD $_{(0.05)}$ & 3.06 & 1.26 & 2.39 & 1.03 \\
\hline
\end{tabular}

$\mathrm{x}=$ Mean of three replicates \pm standard error; $\mathrm{MCP}=$ Multi clonal plots; $\mathrm{DI}=$ Disease index

Rao (1975) stressed that each stand of the Para rubber tree is an economic entity. After canopy closure, the replacement of any missing stand is almost impossible. Therefore, any loss of rubber tree stand should be prevented since it certainly translates into an economic loss throughout the life of the plantation. The rubber tree produces latex for 50 years commercially (Reinhard, 2007), but optimal production is 25 to 30 years (Reinhard, 2007; Verheye, 2010). As shown in this study, a situation where about 40 per cent aggregate failure occurs should not be allowed to continue.

The estimated gross economic loss (N 113, 652.30 to $274,734.30$ ) per year recorded may not justify the retention of such plots as the extrapolation of this figures into possible financial loss per hectare would be enormous. The employment of trained personnel to manage/ control the disease would have been more costeffective. Coupled with this, a low level of awareness of the prevention and control methods of the disease by smallholding rubber farmers may provide the reason why many of them eventually cut down their rubber trees and converted their plots for cultivating other crops. Aigbekaen et al. (2004) reported that the incidence of rubber maladies was generally higher in rubber farmers' plots. This trend would have to be reversed if the rubber industry regains its former glory in Nigeria. 


\section{REFERENCES}

Aigbekaen, E.O., Omokhafe, K.O. andAlrpoja, E.O. 2004. An assessment of the incidence of diseases and pests in rubber plantations in Nigeria. Nigerian Journal of Agriculture and Forestry 1(2): 142-149.

Begho, E.R. and Ekpo, E.J.A. 1987. Incidence and Pathogencity of Rigidoporus lignosus (Klotzsch) Bress. on Triplochiton scleroxylon K. Schum. Plant and Soil 98: 439- 442.

Bodah, E.T. 2017. Root rot diseases in plants: A review of common causal agents and management strategies. Agricultural Research and Technology 5(3): 555661. DOI:10.19080/ARTOAJ.2017.04.555661.

Galliano, H., Gas, G. And Boudet, A.M. 2006. Lignin biodegradation by cultures of Rigidoporus lignosus in solid state conditions. FEMS Microbiology Letters 67(3): 295-299.

Geiger, J.P.B., Nicole, M. and Nandris, D. 1986. Biodegradation of Hevea brasiliensis wood by Rigidoporus lignosus and Phellinus noxius. European Journal of Forest Pathology 16: 147-159.

IRRDB (International Rubber Research and Development Board). 2000. IRRDB Workshop on Corynespora leaf fall of Rubber, 6-9 June, 2000. 2p.

Jayaratne, K., Jayasinghe, C.K. and Wattasinghe, P.C. 1997. Economical and less hazardous fungicides for the management of white root disease. Journal of Rubber Research Institute of Sri Lanka 80: 20-29.

Jayasinghe, C.K. 2010. White root disease of rubber tree: An overview. In: Proceedings of International Workshop on White root rot disease of Hevea Rubber. $14^{\text {th }}-16^{\text {th }}$ Dec. 2010, Hotel Janaki, Colombo, Sri Lanka, 1-8 pp.

Martinez-Ferri, E., Zumaquero, A., Ariza, M.T., Barcelo, A. and Pliego, C. 2016. Non-destructive detection of white root rot disease in avocado root stocks by leaf chlorophyll fluorescence. Plant Disease 100: 49-58.

Nandris, D., Nicole, M. and Geiger, J.P. 1983. Inoculations of young plants of Hevea brasiliensis by Rigidoporus lignosus and Phellinus noxius. European Journal of Plant Pathology 13: 65-76.

Nicole, M.R. and Nicole, B. 1991. Cytochemical aspects of cellulose breakdown during the infection process of rubber tree root Rigidoporus lignosus. Phytopathology 8(11): 1412- 1420 .
Ogbebor, N.O., Adekunle, A.T., Eghafona, O.N. and Ogboghodo, A.I. 2013. Incidence of Rigidoporus lignosus (Klotzsch) Imaz of Para rubber in Nigeria. Researcher 5(12) 181-184.

Ogbebor, O.N., Omorusi, V.I., Orumwense, K. and Ijieh, K. 2014. The status of white root rot in rubber plantations in Nigeria. Journal of Plantation Crops 42(1): 142-144.

Ogbebor, N.O., Adekunle, A.T., Eghafona, O.N. and Ogboghodo, A.I. 2015. Biological control of Rigidoporus lignosus in Hevea brasiliensis in Nigeria. Fungal Biology. 119: 1-6. Journal Elsevier Doi.1016/j. Funbio.2014.10.002.

Ogbebor, O.N., Omorusi, I.V., Agbonlahor, E.H., Daniels, E., Ohiocheoya, B., Ekhaguere, W., Onasoga O.J., Aisagbonhi, M. and Ijie, K. 2019. Status of rubber diseases (Hevea brasiliensis Muell. Arg.) in Nigeria. International Journal of Science and Nature.10(3): 109-114

Otoide, V.O. 1978. Further observation on the pre-treatment of forest trees for root diseases control in Hevea plantings. Paper presented at Rubber Research Institute of Nigeria Seminar.1978, 7p.

Parry, D. 1990. Plant Pathology in Agriculture. Cambridge University Press, Great Britain. 385p.

Rajalakshmy, V.K. and Jayarathnam, K. 2000. Root diseases and non-microbial maladies. In: Natural Rubber: AgroManagement and Crop Processing. (Eds) George, P.J. and Jacob, C. K. Anaswara Printing and Publishing Company, India. 648p.

Rao, B.S. 1975. Maladies of Hevea in Malaysia, Kuala Lumpur. 108p.

Reinhard, L. 2007. South American leaf blight of the rubber tree (Hevea spp.): New steps in plant domestication using physiological features and molecular markers. Annals of Botany 100: 1125-1142.

Suneerat, W., Sayan, S., Charassri, N. and Samerchai, C. 2012. Screening of rubber (Hevea brasiliensis Muell. Arg.) root-stocks for the white root disease resistance. Journal of Agricultural Technology 8: 2385-2395.

Verheye, W. 2010. Land Use, Land Cover and Soil Sciences. Encyclopedia of Life Support Systems (EOLSS), UNESCO-EOLSS Publishers, Oxford, UK. 